\title{
Knowledge and prevalence of trauma and evaluation of the impact of educational and preventive actions on a population of athletes
}

Conhecimento e prevalência de trauma e avaliação do impacto das ações educacionais e preventivas em uma população de atletas

Conocimiento y prevalencia del trauma y evaluación del impacto de las acciones educativas y preventivas en una población de deportistas

Received: 03/15/2021 | Reviewed: 03/22/2021 |Accept: 03/26/2021 | Published: 04/04/2021

Ana Paula Fernandes Ribeiro

ORCID: https://orcid.org/0000-0001-5313-5003 Universidade Estadual Paulista, Brazil E-mail: apf.ribeiro@unesp.br

Ticiane Cestari Fagundes Tozzi ORCID: https://orcid.org/0000-0002-3418-0498 Universidade Estadual Paulista, Brazil E-mail: ticiane.fagundes@unesp.br

Sérgio Tumelero

ORCID: https://orcid.org/0000-0002-3840-7709 Secretaria Municipal de Esporte, Lazer e Recreação de Araçatuba, Brazil E-mail: tumelero.ef@gmail.com

Gabriel Andrade Nunes Carrijo ORCID: https://orcid.org/0000-0001-5710-0545

Universidade Estadual Paulista, Brazil E-mail: gabrielkarrijo@gmail.com

Laura Ramos Vieira

ORCID: https://orcid.org/0000-0002-7828-6809

Universidade Estadual Paulista, Brazil E-mail: laurarvieira@hotmail.com Caroline Loureiro

ORCID: https://orcid.org/0000-0002-9035-2960 Universidade Estadual Paulista, Brazil E-mail: caroline.loureiro@unesp.br

Rogério de Castilho Jacinto

ORCID: https://orcid.org/0000-0002-2362-8920 Universidade Estadual Paulista, Brazil E-mail: rogerio.castilho@unesp.br

\begin{abstract}
This university extension project aimed to verify the knowledge of athletes about dental trauma, the prevalence and type of trauma that occurred in sports, previous use of mouthguards and to evaluate the impact of educational/preventive actions implemented in this population. The study was divided into 1) Application of Questionnaire $1(\mathrm{n}=94)$; 2) Clinical examination and manufacture of mouthguards; 3) Lecture on trauma; 4) Application of questionnaire $2(n=40)$. The data were submitted to descriptive analysis and Fisher's exact test, with a significance of 5\%. Athletes showed little knowledge about dental trauma. The prevalence of trauma and previous use of the protector were higher in athletes in the fighting sports category $(\mathrm{p}<0.05)$. After the lectures, the athletes showed improvement in knowledge about trauma and high adherence to the use of custom-made mouthguards. These results show how extension projects have a positive impact, changing the reality of the population.
\end{abstract}

Keywords: Athletic injuries; Mouth protectors; Tooth injuries; Wounds and injuries; Athletes.

\section{Resumo}

Este projeto de extensão universitária teve como objetivos verificar o conhecimento de atletas sobre traumas dentários, a prevalência e tipo de trauma ocorrido no esporte, uso prévio do protetor bucal e avaliar o impacto das ações educativas/preventivas implementadas nesta população. O estudo foi dividido em: 1) Aplicação do Questionário 1 (n=94); 2) Exame clínico e fabricação de protetores bucais; 3) Palestra sobre trauma; 4) Aplicação do questionário 2 $(\mathrm{n}=40)$. Os dados foram submetidos à análise descritiva e teste exato de Fisher, com significância de $5 \%$. Os atletas demonstraram pouco conhecimento sobre trauma dentário. A prevalência de trauma e uso prévio ao protetor, foram maiores nos atletas da categoria de esportes de luta $(\mathrm{p}<0,05)$ Após as palestras, os atletas apresentaram melhora no 
conhecimento sobre o trauma e alta adesão ao uso de protetores bucais personalizados. Esses resultados mostram como os projetos de extensão impactam positivamente, mudando a realidade da população.

Palavras-chave: Traumatismos em atletas; Protetores bucais; Traumatismos dentários; Ferimentos e lesões; Atletas.

\section{Resumen}

Este proyecto de extensión universitaria tuvo como objetivo verificar el conocimiento de los deportistas sobre el trauma dental, la prevalencia y tipo de trauma ocurrido en el deporte, el uso previo de protectores bucales y evaluar el impacto de las acciones educativas / preventivas implementadas en esta población. El estudio se dividió en: 1) Aplicación del Cuestionario $1(\mathrm{n}=94) ; 2)$ Examen clínico y fabricación de protectores bucales; 3 ) Conferencia sobre trauma; 4) Aplicación del cuestionario $2(\mathrm{n}=40)$. Los datos fueron sometidos a análisis descriptivo y prueba exacta de Fisher, con una significancia del 5\%. Los atletas mostraron poco conocimiento sobre el trauma dental. La prevalencia de trauma y uso previo del protector fue mayor en deportistas de la categoría deportes de lucha ( $p<0,05)$, tras las conferencias, los deportistas mostraron una mejora en el conocimiento sobre el trauma y alta adherencia al uso de protectores bucales personalizados. Estos resultados muestran cómo los proyectos de extensión tienen un impacto positivo, cambiando la realidad de la población.

Palabras clave: Traumatismos en atletas; Protectores bucales; Traumatismos de los dientes; Heridas y traumatismos; Atletas.

\section{Introduction}

Orofacial trauma is considered a public oral health problem due to its high prevalence. In addition to the physical/aesthetic implications, dental injuries have a psychological/emotional impact (I Eroje et al., 2020; Fernandes et al., 2019). The most frequent reasons for the occurrence of these injuries are accidents related to the practice of sports (Galic et al., 2018). These activities collaborate with almost a third of oral injuries, i.e. concussion, fracture, dislocation, and avulsion, in addition to laceration of soft tissues, fractures of the facial bones, and damage of the temporomandibular joint (Dhillon et al., 2014; Bergman et al., 2017).

Direct contact sports, such as handball, basketball, football, and martial arts, result in a higher occurrence of traumas and injuries, as athletes are in physical interaction with objects and with each other (Fernandes et al., 2019). Therefore, both knowledge about dental care for trauma and knowledge of preventive measures are essential for athletes and physical trainers, to minimize the impact of these accidents. For instance, the application of emergency procedures in the event of trauma during sports practice could be provided by individuals present at the moment of the accident, instead of waiting for professional dental assistance (Mori et al., 2009; de Oliveira et al., 2017). A survey carried out by de Oliveira et al,8 with physical education students, showed that $62.3 \%$ of the participants were trained for first aid in general, while only $9.5 \%$ received specific instructions to provide dental first aid in cases of oral trauma. Overall, study participants considered dental first aid training important and declared that educational interventions on dental trauma are essential (de Oliveira et al., 2017).

The use of mouthguards is considered the main protective measure during sports activities, as it reduces orofacial damage, preventing fractures or dislocations of the teeth, thus absorbing or redistributing shock; stabilizes the jaw and protects from bone fractures; reduces lacerations and contusions in soft tissues by cushioning and distributing the force of the impacts. Besides, mouthguards provide support for spaces where there is no dental element (Bergman et al., 2017; Tuna e Ozel, 2014; Knapik et al., 2007). However, despite these benefits, the use of protective devices is not a standard behavior among athletes. Previous studies have shown that there is a low incidence of athletes adept at using mouthguards during sports practice (Mori et al., 2009; Frontera et al., 2011).

According to the American Dental Association, 2020 (ADA) there are three types of mouthguards: stock, boil and bite, and personalized. The stock protectors are pre-formed, that is, they are ready for use. They usually do not adapt properly and interfere with breathing and speech. Boil and bite protectors can be found at sporting goods stores, which are softened in boiling water and inserted and adapted into the athlete's mouth. Finally, the custom-made mouthguards are usually made of 
ethylene-vinyl acetate (EVA), from a plaster model of the athlete's upper arch, adjusted by a dentist. These devices are considered the most satisfactory in several aspects, such as adaptation and practicality (Tuna e Ozel, 2014; ADA, 2020).

Thus, the objectives of this extension project were to verify the knowledge of athletes from the sports delegation of the city of Araçatuba about dental trauma during sports practice, the prevalence and types of dental trauma that occurred during sports activity, and previous use of a mouthguard. In addition, educational and preventive measures were implemented, such as lectures and discussion activities and the provision of custom-made mouthguards, for evaluation of the impact of these actions. The project met a demand from the City Hall of Araçatuba and was carried out in partnership with the Municipal Department of Sports and Culture.

\section{Methodology}

This study was approved by the Institution's Research Ethics Committee, according to resolution 466/12 (CAAE: 1023719.0.0000.5420), and all athletes who agreed to participate in the research signed an informed consent form.

The present study has a qualitative nature, with a descriptive approach, whose results were compared using questionnaires (Pereira et al., 2018). Data were collected between May/2019 and February/2020. The sample consisted of athletes from the Sports Department of the City of Araçatuba, from the sports modalities of Handball, Indoor Soccer, Basketball, Judo, and Karate, comprising both genders. The survey was outlined in four parts: 1) Questionnaire 1 application; 2) Clinical examination and fabrication of mouthguards; 3) Lecture on dental trauma, discussion section, distribution of mouthguards and instructions for use; 4) Questionnaire 2 application.

The inclusion criterion for the first part of the study was that the athletes were over 14 years old. The exclusion criteria established for the second stage of the research were athletes who used orthodontic appliances, who needed prosthetic rehabilitation, and athletes who, due to the rules of the sport, needed double mouthguards. Figure 1 shows the study design.

The sports modalities were divided into two groups, collective sports (CS) and fighting sports (FS). In the collective sports category: handball, basketball, and indoor soccer were included, comprising 83 athletes. Judo and karate represented the fighting sports category, with 11 athletes. Participants who belonged to the junior category were between $\geq 14$ and $<18$ years old $\left(\mathrm{X}^{-}=15.5\right.$ and $\left.\sigma=1.3\right)$, while the senior category comprised athletes $\geq 18$ years old $\left(\mathrm{X}^{-}=30.1\right.$ and $\left.\sigma=9\right)$. All athletes participated in official regional and interstate competitions. The municipal delegation does not include players with physical and intellectual disabilities.

\section{1) Application of the questionnaire 1}

The first questionnaire (Figure 2) was adapted from Keçeci et al. The questions were divided into three categories: general information, orofacial injury, and use of mouthguards.

All athletes linked to the sports delegation $(n=107)$ were assessed for eligibility, 94 of them aged 14 or over, participated in the study. The research addressed issues related to knowledge about oral first aid, prevalence, and type of orofacial trauma that occurred during sports practice and knowledge and habits of using the mouth guard. The research team personally applied the first questionnaire to the athletes, clarifying doubts, when necessary. Each athlete received and answered only one questionnaire.

\section{2) Clinical examination and fabrication of mouthguards}

Judo participants $(n=7)$ were excluded from the second stage of the study because it is a sport requiring the use of double mouthguards. Athletes who were undergoing orthodontic treatment $(n=25)$ were also excluded from this stage. In all, 
62 athletes received an invitation to participate in this phase of the project. The request was made directly, by email, by messaging application, and/or phone call.

The athletes were examined clinically and radiographically. Athletes in need of prosthetic rehabilitation $(n=5)$ and who could not be contacted $(n=12)$ were excluded from the study. A total of 45 athletes were molded to obtain the upper and lower plaster model. The impressions were made with alginate impression material (Avagel-Dentsply, São Paulo, Brazil). Participants who needed dental treatment were referred to undergraduate students' clinics at the State University of São Paulo (UNESP), School of Dentistry, Araçatuba.

For the manufacture of custom-made mouthguards, it was used A vacuum-forming machine (Plastvac P7, Bio-Art 127 V, São Carlos, Brazil), together with transparent EVA plates, 3 and 4 mm-thick (Bio-Arte, São Carlos, Brazil). The upper plaster model, previously cut and prepared, was positioned in the machine's model holder. The first EVA plate (4 mm) was heated for 2 minutes and 30 seconds and lowered to the upper model, the vacuum remaining 30 seconds. This first plate was cut with iris scissors (Golgran, São Caetano do Sul, Brazil) and Maxicut drill (Edenta, Moema, Brazil) according to the athlete's oral anatomy and extending to the distal region of the upper first molar and respecting the oral anatomy of each athlete. The second EVA plate ( $3 \mathrm{~mm}$ ) was heated for 2 minutes (Collares et al., 2014) and lowered in the model and first plate set, also remaining in a vacuum for 30 seconds. The lower plaster model was positioned on the upper model, simulating the patient's occlusion, to promote better adjustment and adaptation of the device. In total, 42 custom-made mouthguards were fabricated. 
Figure 1. Study design.

\section{Enrollment}

Assessed for eligibility $(\mathrm{n}=107)$

Excluded $(n=13)$ - under 14 years

\section{Allocation}

Allocated to questionnaire $1(\mathrm{n}=94)$

\section{Analysis}

Analysed $(n=94)$

\section{Enroliment}

Assessed for eligibility $(\mathrm{n}=94)$

- Excluded $(\mathrm{n}=32)$

- Reason: use of orthodontic braces $(\mathrm{n}=25)$; need for double mouthguard $(\mathrm{n}=7)$

\section{Allocation}

Allocated to intervention $(\mathrm{n}=62)$

- Received allocated intervention $(n=45)$

- Excluded $(\mathrm{n}=17)$

- Reasons: could not be contacted $(\mathrm{n}=12)$ need of prosthetic rehabilitation $(n=5)$

\section{Follow-Up}

Lost to follow-up ( $\mathrm{n}=2$ )

- Reasons:

- did not answer the questionnaire $2(\mathrm{n}=2)$

- started an orthodontic treatment $(\mathrm{n}=1)$

- gave up to participate $(\mathrm{n}=2)$

\section{Analysis}

Analysed $(n=40)$

- Excluded from analysis (give reasons) $(\mathrm{n}=0)$ 
Research, Society and Development, v. 10, n. 4, e16210413913, 2021

(CC BY 4.0) | ISSN 2525-3409 | DOI: http://dx.doi.org/10.33448/rsd-v10i4.13913

Figure 2. Questionnaire 1.

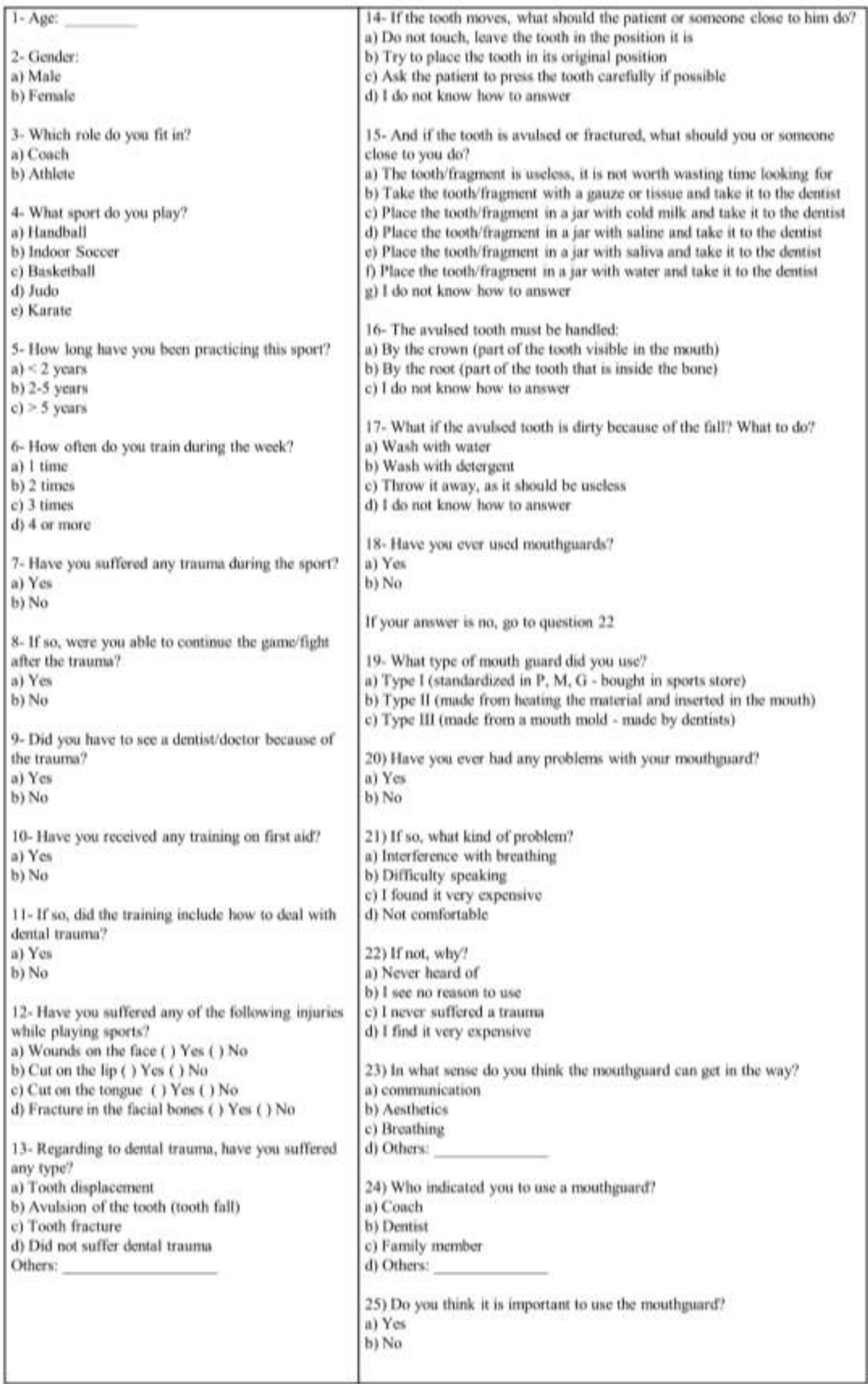

Source: Authors. 
3) Lecture on dental trauma, discussion section, distribution of mouthguards, and instructions for use

The lectures were given separately for each sport, at the training sites of each team. The content was presented expositive (powerpoint presentation) by members of the research team.

The presentation addressed the injuries that occur more frequently during sports such as tooth displacement, fracture, and tooth avulsion, thus providing instructions on how to deal with first aid procedures. The correct handling in each situation was addressed: repositioning the tooth to its original position in cases of displacement; store the lost dental fragment in solution (cold milk) and take it to the dentist, when a dental fracture occurs; immediately replant the avulsed tooth and if it is not possible, take it in solution (cold milk) to the dentist. This content was also made available in portable document format (PDF) so that athletes could access the content later.

Then, the discussion section was opened so that athletes could ask questions, report their previous experiences with oral trauma, their thoughts regarding the importance of the preventive measures, and their concern with the possibility of suffering injuries during sports practices, which could be minimized by implementing the knowledge recently acquired. Afterward, the athletes received their custom-made mouthguards and were instructed on how to use and how to take care of the device. In addition, they were asked to use it during both training and official championships and to contact the research team if any adjustment of the device was necessary.

\section{4) Questionnaire 2 application}

The second questionnaire (Figure3) was applied to 40 athletes, 30 days after using custom-made mouthguards. This questionnaire contained questions about the topics covered in the lecture, in order to carry out a new assessment of the athlete's knowledge about oral first aid and to verify the use and adaptation of the custom-made mouthguard. Thus, it was possible to verify the impact of the actions promoted in this community.

\section{5) Analyses of the results}

For statistical analysis, the collected data were tabulated in Excel spreadsheets and submitted to statistical analysis in the SigmaPlot 12.0 program (Systat Software Inc., San Jose, USA), using Fisher's Exact test, with a significance level of 5\% and descriptive statistics. 
Figure 3. Questionnaire 2.

1- What sports do you play?
a) Handball
b) Indoor Soccer
c) Basketball
d) Karate
2- Gender
a) Male
b) Female
3- If the tooth moves, what should the patient or
someone close to him do?

a) Do not touch, leave the tooth in the position it is

b) Try to put the tooth in its original position and go to the dentist

c) Ask the patient to press the tooth carefully

d) I do not know how to answer

4- If the tooth is broken what should you or someone close to you do?

a) The lost fragment is useless, it is not worth wasting time looking for

b) Take the dental fragment with gauze or tissue and take it to the dentist

c) Place the dental fragment in a jar with a solution and take it to the dentist

5-If the tooth is avulsed, what should you or someone close to you do?

a) The tooth is useless, it is not worth wasting time looking for

b) Redeploy (replace) the tooth and go to the dentist c) Do not try to do anything, just take the tooth to the dentist

d) I do not know how to answer

6- What is the best solution to place the fragment/avulsed tooth?

a) Place the fragment in a jar with cold milk and take it to the dentist

b) Place the fragment in a jar with saline and take it to the dentist

c) Place the fragment in a jar with saliva and take it to the dentist

d) Place the fragment in a jar with water and take it to the dentist

e) I do not know how to answer
7- The avulsed tooth must be handled:

a) By the crown (part of the tooth visible in the mouth)

b) By the root (part of the tooth that is inside the bone)

c) I do not know how to answer

8- If the avulsed tooth is dirty because of the fall, what to do?

a) Wash gently with water

b) Wash with detergent

c) Throw it away, as it should be useless

d) I do not know how to answer

9- Are you using the mouthguard?

a) Yes

b) No

If your answer to this question is "NO", go to question number 14

10- Were you able to adapt easily to the use of the mouthguard?

a) Yes

b) No

11- Are you having any problems with your mouthguard?

a) Yes

b) No

12-If so, what kind of problem?

a) Interference with breathing

b) Difficulty speaking

c) Not comfortable

d) It is not aesthetic

e) All of the above

13- Would you recommend the use of mouthguards to other athletes?

a) Yes

b) No

14- Why are you not using the mouthguard?

a) I could not adapt

b) The protector hurts

Source: Authors.

\section{Results}

A significant percentage of participants, of both categories, did not have consistent knowledge to provide first aid in the event of a trauma episode, $98.3 \%$ of the athletes in collective sports and $88.9 \%$ of the fighting sports, never received first 
aid instructions dental aid ( $p>0.05)$. Table 1 shows the descriptive analysis of the responses on knowledge of trauma between sports categories.

Table 1. Knowledge of trauma between sports categories.

\begin{tabular}{|c|c|c|}
\hline \multicolumn{3}{|l|}{ Questionnaire 1} \\
\hline \multicolumn{3}{|l|}{ If the tooth moves, what should the patient or someone close to him do? } \\
\hline & CS $(\%)$ & FS $(\%)$ \\
\hline a) Do not touch, leave the tooth in the position it is & 47,0 & 54,4 \\
\hline b) Try to place the tooth in its original position & 2,4 & 0,0 \\
\hline c) Ask the patient to press the tooth & 13,3 & 9,1 \\
\hline d) I do not know how to answer & 36,1 & 36,4 \\
\hline \multicolumn{3}{|c|}{ If the tooth is avulsed or fractured, what should you or someone close to you do? } \\
\hline & $\mathrm{CS}(\%)$ & $\mathrm{FS}(\%)$ \\
\hline a) The tooth/fragment is useless, not worth looking for & 0,0 & 9,1 \\
\hline $\begin{array}{l}\text { b) Take the tooth/fragment with a gauze or tissue and take it to } \\
\text { the dentist }\end{array}$ & 49,4 & 36,4 \\
\hline $\begin{array}{l}\text { c) Place the tooth/fragment in a jar with cold milk and take it } \\
\text { to the dentist }\end{array}$ & 2,4 & 9,1 \\
\hline $\begin{array}{l}\text { d) Place the tooth/fragment in a jar with saline and take it to } \\
\text { the dentist }\end{array}$ & 4,8 & 9,1 \\
\hline $\begin{array}{l}\text { e) Place the tooth/fragment in a jar with saliva and take it to } \\
\text { the dentist }\end{array}$ & 0,0 & 0,0 \\
\hline $\begin{array}{l}\text { f) Place the tooth/fragment in a pot of water and take it to the } \\
\text { dentist }\end{array}$ & 7,2 & 0,0 \\
\hline g) I do not know how to answer & 36,1 & 36,4 \\
\hline
\end{tabular}

\begin{tabular}{lcc}
\hline The avulsed tooth must be handled: & & \\
& CS $(\%)$ & FS $(\%)$ \\
\hline a) By the crown & 22,9 & 18,2 \\
b) By the root & 10,8 & 18,2 \\
c) I do not know how to answer & 61,4 & 63,6 \\
\hline
\end{tabular}

\begin{tabular}{lcc}
\hline What to do if the avulsed tooth is dirty from falling? & & \\
& CS $(\%)$ & FS $(\%)$ \\
\hline a) Wash with water & 61,4 & 27,3 \\
b) Wash with detergent & 0,0 & 0,0 \\
c) Throw it away, it should be useless & 0,0 & 24,3 \\
d) I do not know how to answer & 34,9 & 45,5 \\
\hline
\end{tabular}

The answers in italics are the correct alternatives. Source: Authors. 
Athletes in the fighting sports category were the ones who most reported the occurrence of orofacial trauma (70\%), only $34.9 \%$ of participants in collective sports reported this type of trauma ( $<<0.05)$. Table 2 shows the descriptive analysis of the prevalence of dental trauma among sports categories and the most frequent dental injuries. Due to the trauma episodes, $54.5 \%$ of FS participants and $32.1 \%$ of CS, needed to seek medical or dental care ( $p>0.05$ ).

Table 2. Prevalence of most frequent dental injuries

\begin{tabular}{lrrrrrr}
\hline & \multicolumn{2}{c}{ Prevalence } & \multicolumn{2}{c}{ Dental fracture } & \multicolumn{2}{c}{ Tooth avulsion } \\
& $\mathrm{n}$ & $\%$ & $\mathrm{n}$ & $\%$ & $\mathrm{n}$ & $\%$ \\
\hline Collective sports & 15 & 18,1 & 10 & 12,0 & 4 & 4,8 \\
Fighting sports & 6 & 54,5 & 2 & 18,2 & 2 & 18,2 \\
\hline
\end{tabular}

Source: Authors.

Previous use of mouthguards was greater in fighting sports (45.5\%) and very little reported by collective sports athletes $(17.5 \%)(\mathrm{p}<0.05)$. None of the participants described having used a custom-made mouthguard previously, and the boiland-bite mouthguard was the most used among the participants of the two sports categories, $75 \%$ FS and 61.5\% CS (p>0.05).

After the lectures, it was noted that the athletes were safer to deal with dental trauma, demonstrating the effectiveness and importance of educational activities. Table 3 shows the data from the descriptive analysis of the answers about knowledge of trauma in the collective sports category, after the lectures. Preventive work improved adherence to the use of mouthguards, as $72.5 \%$ of CS athletes started using custom-made mouthguards during sports activities and $62.5 \%$ were able to adapt to the protective device, confirming the positive impact of preventive action.

Table 3. Knowledge of CS trauma, after educational work

\begin{tabular}{lc}
\hline \multicolumn{1}{c}{ Questionnaire 2 } & $\%$ \\
\hline If the tooth moves, what should the patient or someone close to him do? & 20,0 \\
\hline a) Do not touch, leave the tooth in the position it is & 70,0 \\
b) Try to put the tooth in its original position and go to the dentist & 10,0 \\
c) Ask the patient to press the tooth carefully & 0,0 \\
d) I do not know how to answer & $\%$ \\
\hline & 0,0 \\
\hline If the tooth is broken what should you or someone close to you do? & 22,5 \\
\hline a) The lost fragment is useless, it is not worth wasting time looking for & 77,5 \\
b) Take the dental fragment with gauze or tissue and take it to the dentist & $\%$ \\
c) Place the dental fragment in a jar with a solution and take it to the dentist & 2,5 \\
\hline df the tooth is avulsed what should you or someone close to you do? & 52,5 \\
\hline a) The tooth is useless, it is not worth wasting time looking for & 32,5 \\
\hline b) Implant (place) the tooth and go to the dentist & 12,5 \\
\hline
\end{tabular}




\begin{tabular}{lc}
\hline What is the best solution to place the fragment/avulsed tooth? & $\%$ \\
\hline a) Place the fragment in a jar with cold milk and take it to the dentist & 65,0 \\
b) Place the fragment in a jar with saline and take it to the dentist & 17,5 \\
c) Put the fragment in a jar with saliva and take it to the dentist & 2,5 \\
d) Place the fragment in a pot of water and take it to the dentist & 7,5 \\
e) I do not know how to answer & 7,5 \\
\hline
\end{tabular}

\begin{tabular}{lc}
\hline The avulsed tooth must be handled: & $\%$ \\
\hline a) By the crown & 82,5 \\
b) By the root & 10,0 \\
c) I do not know how to answer & 7,5 \\
\hline
\end{tabular}

\begin{tabular}{lc}
\hline If the avulsed tooth is dirty from falling, what would you do? & $\%$ \\
\hline a) Wash gently with water & 90,0 \\
b) Wash with detergent & 0,0 \\
c) Throw it away, it should be useless & 5,0 \\
d) I do not know how to answer & 5,0 \\
\hline
\end{tabular}

The answers in italics are the correct alternatives. Source: Authors.

\section{Discussion}

This study identified the athletes' lack of information about dental first aid and the low adherence to mouthguards during sports activities. Some studies have also identified this information deficiency to deal with trauma episodes and pointed out the need for educational work in this population (Fernandes et al., 2019; Galic et al., 2018; Bergman et al., 2017; Frontera et al., 2011; Keçeci et al., 2005). The differential of the present study was exactly the accomplishment of the educational measures and the implementation of the preventive action. Through the lectures, the athletes acquired knowledge and received specific instructions to provide first aid in the face of trauma. The making and distribution of mouthguards, made under the oral anatomy of each athlete, increased adherence to the use of protective devices.

Sports practice is one of the main etiological factors of dental trauma (Yeşil Duymuş e Gungor, 2009). In this study, there was a high prevalence of orofacial and dental trauma in athletes who play fighting sports (judo and karate). These findings are in agreement with data in the literature, which point to a high chance of trauma in sports of direct physical contact (Fernandes et al., 2019; Bruggesser et al., 2020). However, there was a moderate prevalence of trauma in athletes in the collective sports category (handball, basketball, and indoor soccer), differing from previous reports (Fernandes et al., 2019; Bruggesser et al., 2020) since these modalities are also considered as sports of direct physical contact.

Trauma from sports can often be reduced with appropriate preventive measures, such as the use of mouthguards, which are proven to be effective in preventing damage to stomatognathic structures (Mizuhashi e Koide, 2019; Duarte-Pereira et al., 2008; Duddy et al., 2012; Gialain et al., 2017). However, as observed in this study and demonstrated in previous studies (Knapik et al., 2007; Goswami et al., 2017), most athletes are not adept at using mouthguards. It would be fundamental and of great importance that the sports federations implement the mandatory use of this protective equipment during activities on the court, thus a significant reduction in orofacial damage would occur. 
Some factors, such as breathing and speech difficulties, aesthetics, high cost of mouthguards, and the lack of encouragement from coaches (Fernandes et al., 2019; Goswami et al., 2017), have been constantly mentioned by athletes, as a justification for not using protective devices. Regarding the cost of these devices, especially the custom-made mouthguard, the dentist must explain that it can provide the athlete a better fit in the oral cavity, greater protection for teeth, bones, and soft tissues. In addition, it causes less interference with oral function, improving the discomfort of breathing and speech (ZamoraOlave et al., 2020), justifying its cost-benefit.

Education on the effectiveness of properly adjusted mouthguards for injury prevention, information on the risk of injury, and the manufacture of custom-made mouthguards, leads to the development of a more positive attitude and the increase in its use. After the athletes' awareness work, there was a better acceptance for the use of the mouthguard, since the majority of the athletes claimed to have used and adapted to the custom-made mouthguard, made by the research team.

A limitation of this study was the quantitative loss of the sample. During the stages of the work, the athletes stopped coming to make the mouthguards and to apply the second questionnaire, which aimed to assess the impact of educational and preventive actions. Some measures, such as continuous communication with athletes and coaches since the first contact, were adopted in order to motivate the athlete to participate in all phases of the research. Even after the distribution of mouthguards, the research team was available to assist and make protectors for athletes who failed to attend this stage, but even so, there was a significant loss of the sample.

Frontera e colaboradores reported that the desire of athletes to have a dentist composing the sports team. The presence of a dental surgeon in the sports delegation would be essential to apply first aid training to coaches and athletes, or even to provide immediate care after the occurrence of trauma. In addition, the health promoter could encourage athletes to use mouthguards and even make these devices for athletes.

This work showed that there is still a lack of information on how to deal with and how to prevent trauma in this population that is highly exposed to the occurrence of orofacial trauma. He also highlighted how the extension projects bring athletes and coaches together with students and health professionals so that the research team can exercise its role of guiding and promoting health and thus actively acting in the community.

\section{Conclusion}

The present study showed, through university extension, how educational and preventive intervention actions can positively impact a population, in this case in particular a population of athletes. After the lectures, the athletes demonstrated greater knowledge and security to deal with dental trauma. Also, they became adept at using custom-made mouthguards during official training and games, contributing to the prevention of orofacial trauma.

Projects like this must be constantly applied in communities, seeking to contribute actively to society, since this can change the reality of the population. In addition, future research implement the same methods involving a bigger sample size and athletes from different geographical location would be of great value. Other analysis of the positive influence of the use of mouthguards in the physical performance of the athletes are important data that would stimulate the regular use of these devices during sports practice.

\section{Acknowledgments}

This work was supported by the Brazilian Agency for the Coordination of the Improvement of Higher Education Personnel - CAPES (process n⿳o 88882.435544/2019-01) and PROEX - UNESP (Edital nº8/2018). We thank Dr. Luiz Pinto de Carvalho for the intermediary of the company BIO-ART and to Dr. Juliana Caires Felipe Bersanete, for her assistance with 
the protection of mouthguards. Dental prosthesis technician Franciane Silva Borges Medga, for her support in the confection of mouthguards. The company BIO-ART for the donation of materials used in the manufacture of custom-made mouthguards. We also would like to thank the "Secretaria Municipal de Esporte, Lazer e Recreação de Araçatuba"

\section{References}

ADA- American Dental Association. Mouthguards. https://www.mouthhealthy.org/en/az-topics/m/mouthguards.

Bergman, L., Milardović Ortolan, S., Žarković, D., Viskić, J., Jokić, D., \& Mehulić, K. (2017). Prevalence of dental trauma and use of mouthguards in professional handball players. Dental traumatology: official publication of International Association for Dental Traumatology, 33(3), 199-204. https://doi.org/10.1111/edt.12323

Bruggesser, S., Kühl, S., Solakoglu, Ö, \& Filippi, A. (2020). The prevalence of orofacial injuries in judo: A cross-sectional study. Dental traumatology: official publication of International Association for Dental Traumatology, 36(4), 411-416. https://doi.org/10.1111/edt.12547

Collares, K., Correa, M. B., Mohnsam da Silva, I. C., Hallal, P. C., \& Demarco, F. F. (2014). Effect of wearing mouthguards on the physical performance of soccer and futsal players: a randomized cross-over study. Dental traumatology: official publication of International Association for Dental Traumatology, 30(1), 55-59. https://doi.org/10.1111/edt.12040

de Oliveira, D. L., Ribeiro-Junior, P. D., Sbroggio, A. C., Dos Santos, P. G., \& Mori, G. G. (2017). Evaluation of Knowledge of Physical Education Students on Dental Trauma. Annals of maxillofacial surgery, 7(2), 217-221. https://doi.org/10.4103/ams.ams_115_17

Dhillon, B. S., Sood, N., Sood, N., Sah, N., Arora, D., \& Mahendra, A. (2014). Guarding the precious smile: incidence and prevention of injury in sports: a review. Journal of international oral health: $\mathrm{JIOH}, 6(4), 104-107$.

Duarte-Pereira, D. M., Del Rey-Santamaria, M., Javierre-Garcés, C., Barbany-Cairó, J., Paredes-Garcia, J., Valmaseda-Castellón, E., Berini-Aytés, L., \& GayEscoda, C. (2008). Wearability and physiological effects of custom-fitted vs self-adapted mouthguards. Dental traumatology: official publication of International Association for Dental Traumatology, 24(4), 439-442. https://doi.org/10.1111/j.1600-9657.2008.00595.x

Duddy, F. A., Weissman, J., Lee, R. A., Sr, Paranjpe, A., Johnson, J. D., \& Cohenca, N. (2012). Influence of different types of mouthguards on strength and performance of collegiate athletes: a controlled-randomized trial. Dental traumatology: official publication of International Association for Dental Traumatology, 28(4), 263-267. https://doi.org/10.1111/j.1600-9657.2011.01106.x

Fernandes, L. M., Neto, J., Lima, T., Magno, M. B., Santiago, B. M., Cavalcanti, Y. W., \& de Almeida, L. (2019). The use of mouthguards and prevalence of dento-alveolar trauma among athletes: A systematic review and meta-analysis. Dental traumatology: official publication of International Association for Dental Traumatology, 35(1), 54-72. https://doi.org/10.1111/edt.12441

Frontera, R. R., Zanin, L., Ambrosano, G. M., \& Flório, F. M. (2011). Orofacial trauma in Brazilian basketball players and level of information concerning trauma and mouthguards. Dental traumatology: official publication of International Association for Dental Traumatology, 27(3), 208-216. https://doi.org/10.1111/j.1600-9657.2009.00781.x

Galic, T., Kuncic, D., Poklepovic Pericic, T., Galic, I., Mihanovic, F., Bozic, J., \& Herceg, M. (2018). Knowledge and attitudes about sports-related dental injuries and mouthguard use in young athletes in four different contact sports-water polo, karate, taekwondo and handball. Dental traumatology: official publication of International Association for Dental Traumatology, 34(3), 175-181. https://doi.org/10.1111/edt.12394

Gialain, I. O., Kobayashi-Velasco, S., Caldeira, C. L., \& Cavalcanti, M. (2017). Dental trauma prevention with mouthguard in a nose fracturing blow to the face: Case report. Dental traumatology: official publication of International Association for Dental Traumatology,33(5), 410-413. https://doi.org/10.1111/edt.12343

Goswami, M., Kumar, P., \& Bhushan, U. (2017). Evaluation of Knowledge, Awareness, and Occurrence of Dental Injuries in Participant Children during Sports in New Delhi: A Pilot Study. International journal of clinical pediatric dentistry, 10(4), 373-378. https://doi.org/10.5005/jp-journals-10005-1468

I Eroje, A. B., Tikare, S., AlQahtani, N. A., Braimoh, O. B., Sundarraj, R. K., Muteq, M. A., Alshehri, A. A., Almanadiah, A. S., \& Albargi, A. M. (2020). Orofacial trauma awareness among sports teachers in Southern Saudi Arabia. Nigerian journal of clinical practice, 23(3), 343-348. https://doi.org/10.4103/njcp.njcp_466_19

Keçeci, A. D., Eroglu, E., \& Baydar, M. L. (2005). Dental trauma incidence and mouthguard use in elite athletes in Turkey. Dental traumatology: official publication of International Association for Dental Traumatology, 21(2), 76-79. https://doi.org/10.1111/j.1600-9657.2004.00302.x

Knapik, J. J., Marshall, S. W., Lee, R. B., Darakjy, S. S., Jones, S. B., Mitchener, T. A., delaCruz, G. G., \& Jones, B. H. (2007). Mouthguards in sport activities: history, physical properties and injury prevention effectiveness. Sports medicine (Auckland, N.Z.), 37(2), 117-144. https://doi.org/10.2165/00007256-200737020-00003

Mizuhashi, F., \& Koide, K. (2019). Vacuum-formed mouthguard fabrication to obtain proper fit using notched sheet. Dental traumatology: official publication of International Association for Dental Traumatology, 35(3), 204-211. https://doi.org/10.1111/edt.12463

Mori, G. G., de Mendonça Janjácomo, D. M., Castilho, L. R., \& Poi, W. R. (2009). Evaluating the knowledge of sports participants regarding dental emergency procedures. Dental traumatology: official publication of International Association for Dental Traumatology,25(3), 305-308. https://doi.org/10.1111/j.1600-9657.2009.00786.x

Pereira, S. A., Shitsuka, D. M., Parreira, F. J., Shitsuka, R. (2018). Metodologia da pesquisa científica. UFSM. 
Research, Society and Development, v. 10, n. 4, e16210413913, 2021

(CC BY 4.0) | ISSN 2525-3409 | DOI: http://dx.doi.org/10.33448/rsd-v10i4.13913

Tuna, E. B., \& Ozel, E. (2014). Factors affecting sports-related orofacial injuries and the importance of mouthguards. Sports medicine (Auckland, N.Z.), 44(6), 777-783. https://doi.org/10.1007/s40279-014-0167-9

Yeşil Duymuş, Z., \& Gungor, H. (2009). Use of mouthguard rates among university athletes during sport activities in Erzurum, Turkey. Dental traumatology: official publication of International Association for Dental Traumatology, 25(3), 318-322. https://doi.org/10.1111/j.1600-9657.2009.00769.x

Zamora-Olave, C., Willaert, E., Parera, L., Riera-Puñet, N., \& Martinez-Gomis, J. (2020). Experience with mouthguards and prevalence of orofacial injuries among field hockey players in Catalonia. Dental traumatology: official publication of International Association for Dental Traumatology, 36(3), 285290. https://doi.org/10.1111/edt.12531 